\title{
RETRACTION
}

The following three articles were withdrawn upon request of their authors on October 3, 2014, because they were submitted without the consent of all the authors.

\section{Retraction: Representation of Dephosphorization Ability for CaO- Containing Slags Based on the Ion and Molecule Coexistence Theory}

Peng-cheng $\mathrm{LI}^{1,2)}$ and Jian-liang ZHANG ${ }^{1)}$

1) State Key Laboratory of Advanced Metallurgy, University of Science and Technology Beijing, Beijing, 100083 P. R. China.

2) State Key Laboratory of Multiphase Complex Systems, Institute of Process Engineering, Chinese Academy of Sciences,

Beijing, 100190 P. R. China.

This article was published in ISIJ Int., 54 (2014), No. 3, 567-577.

\section{Retraction: A Prediction Model of Phosphorus Distribution between $\mathrm{CaO}-\mathrm{SiO}_{2}-\mathrm{MgO}-\mathrm{FeO}-\mathrm{Fe}_{2} \mathrm{O}_{3}-\mathrm{P}_{2} \mathrm{O}_{5}$ Slags and Liquid Iron}

Peng-cheng $\mathrm{LI}^{1,2,3)}$ and Jian-liang ZHANG ${ }^{1,2)}$

1) State Key Laboratory of Advanced Metallurgy, University of Science and Technology Beijing, Beijing, 100083 P. R. China.

2) School of Metallurgical and Ecological Engineering, University of Science and Technology Beijing, Beijing, 100083 P. R.

China.

3) State Key Laboratory of Multiphase Complex Systems, Institute of Process Engineering, Chinese Academy of Sciences, Beijing, 100190 P. R. China.

This article was published in ISIJ Int., 54 (2014), No. 4, 756-765.

\section{Retraction: Representation of Reaction Ability for Structural Units in Fe-Al Binary Melts}

Peng-cheng $\mathrm{LI}^{1,2,3)}$ and Jian-liang ZHANG ${ }^{1,2)}$

\footnotetext{
1) State Key Laboratory of Advanced Metallurgy, University of Science and Technology Beijing, Beijing, 100083 P. R. China.

2) School of Metallurgical and Ecological Engineering, University of Science and Technology Beijing, Beijing, 100083 P. R. China.

3) State Key Laboratory of Multiphase Complex Systems, Institute of Process Engineering, Chinese Academy of Sciences, Beijing, 100190 P. R. China.
}

This article was published in ISIJ Int., 54 (2014), No. 6, 1185-1194. 


\title{
Representation of Reaction Ability for Structural Units in Fe-Al Binary Melts
}

\author{
Peng-cheng $\mathrm{LI}^{1,2,3) *}$ and Jian-liang $\mathrm{ZHANG}^{1,2)}$
}

1) State Key Laboratory of Advanced Metallurgy, University of Science and Technology Beijing, Beijing, 100083 P. R. China.

2) School of Metallurgical and Ecological Engineering, University of Science and Technology Beijing, Beijing, 100083 P. R. China.

3) State Key Laboratory of Multiphase Complex Systems, Institute of Process Engineering, Chinese Academy of Sciences, Beijing, 100190 P. R. China.

(Received on October 5, 2013; accepted on January 9, 2014)

\begin{abstract}
$$
\begin{array}{lll}
\ln \gamma_{\mathrm{Al}}=-3.810+4.476 x_{\mathrm{Al}} & 0<x_{\mathrm{Al}} \leq 0.005, & T=1573 \mathrm{~K} \\
\ln \gamma_{\mathrm{Al}}=-3.397+4.248 x_{\mathrm{Al}} & 0<x_{\mathrm{Al}} \leq 0.005, & T=1673 \mathrm{~K} \\
\ln \gamma_{\mathrm{Al}}=-3.056+4.011 x_{\mathrm{Al}} & 0<x_{\mathrm{Al}} \leq 0.005, & T=1773 \mathrm{~K} \\
\ln \gamma_{\mathrm{Al}}=-2.537+3.599 x_{\mathrm{Al}} & 0<x_{\mathrm{Al}} \leq 0.005, & T=1873 \mathrm{~K} \\
\ln \gamma_{\mathrm{Fe}}=-3.837+6.701 x_{\mathrm{Fe}} & 0<x_{\mathrm{Fe}} \leq 0.005, & T=1573 \mathrm{~K} \\
\ln \gamma_{\mathrm{Fe}}=-3.753+7.627 x_{\mathrm{Fe}} & 0<x_{\mathrm{Fe}} \leq 0.005, & T=1673 \mathrm{~K} \\
\ln \gamma_{\mathrm{Fe}}=-3.701+8.066 x_{\mathrm{Fe}} & 0<x_{\mathrm{Fe}} \leq 0.005, & T=1773 \mathrm{~K} \\
\ln \gamma_{\mathrm{Fe}}=-3.686+8.176 x_{\mathrm{Fe}} & 0<x_{\mathrm{Fe}} \leq 0.005, & T=1873 \mathrm{~K}
\end{array}
$$
\end{abstract}
A thermodynamic model for calculating the mass action concentrations of structural units in Fe-Al binary melts based on the atom-molecule coexistence theory, i.e., AMCT- $N_{i}$ model, has been developed and verified through comparing with the reported activities of both $\mathrm{Al}$ and $\mathrm{Fe}$ in $\mathrm{Fe}-\mathrm{Al}$ binary melts in a temperature from $1573 \mathrm{~K}$ to $1873 \mathrm{~K}$ by different researchers. The calculated mass action concentration $N_{\mathrm{Al}}$ of $\mathrm{Al}$ or $N_{\mathrm{Fe}}$ of $\mathrm{Fe}$ can be applied to ideally substitute the measured activity $a_{\mathrm{R}}$, Al of $\mathrm{Al}$ or $a_{\mathrm{R}}$, Fe of $\mathrm{Fe}$ relative to pure liquid $\mathrm{Al}(\mathrm{I})$ or $\mathrm{Fe}(\mathrm{I})$ as standard state in Fe-Al binary melts. The following equations were derived for the activity coefficient of Al in natural logarithmic form $\ln \gamma_{\mathrm{Al}}$ and the calculated activity coefficient of $\mathrm{Fe}$ in natural logarithmic form $\mathrm{In} \gamma_{\mathrm{Fe}}$ in the temperature range from $1573 \mathrm{~K}$ to $1873 \mathrm{~K}$.

Temperature dependences of the activity coefficient of $A l$ in natural logarithmic form $\ln \gamma_{A l}^{0}$ and the calculated activity coefficient of $\mathrm{Fe}$ in natural logarithmic form $\ln \gamma_{\mathrm{Fe}}^{0}$ were given

$$
\begin{array}{ll}
\ln \gamma_{\mathrm{Al}}^{0}=2.6917-10222.7 / T & 1573 \mathrm{~K} \leq T \leq 1873 \mathrm{~K} \\
\ln \gamma_{\mathrm{Fe}}^{0}=-2.8573-1521.6816 / T & 1573 \mathrm{~K} \leq T \leq 1873 \mathrm{~K}
\end{array}
$$

The obtained values were compared with the results of the previous investigations.

KEY WORDS: Fe-Al binary melts; activity of aluminum; activity of iron; mass action concentration; reaction ability; thermodynamic model; structural units; atom and molecule coexistence theory (AMCT).

\section{Introduction}

The knowledge of the thermodynamics of Fe-Al binary melts is important both from a process metallurgy point of view and for an understanding of the thermochemical behavior of fiber-reinforced iron aluminized composites. ${ }^{1)}$ For these reasons, the reaction abilities of elements, especially activity coefficient $\gamma_{\mathrm{Al}}$ of $\mathrm{Al}$ and $\gamma_{\mathrm{Fe}}$ of $\mathrm{Fe}$ in $\mathrm{Fe}-\mathrm{Al}$ binary melts have attracted tremendous attention in the past several decades. ${ }^{2-10)}$ Chipman and Floridis ${ }^{2)}$ measured the distribution of aluminum between liquid iron and silver, and combined these data to extrapolate activate coefficient $\gamma_{\mathrm{Al}}$ of

\footnotetext{
* Corresponding author: E-mail: lipengcheng000@126.com DOI: http://dx.doi.org/10.2355/isijinternational.54.1185
}

$\mathrm{Al}$ in $\mathrm{Fe}-\mathrm{Al}$ binary melts up to 9.66 mass $\% \mathrm{Al}$ at $1873 \mathrm{~K}$ as $\gamma_{\mathrm{Al}}=-3.477+6.0 X_{\mathrm{Al}}$. Wilder and Elliott ${ }^{3)}$ determined the activity of aluminum in liquid $\mathrm{Al}-\mathrm{Ag}$ alloys between $973 \mathrm{~K}$ and $1173 \mathrm{~K}$ by a galvanic cell technique, and their results were extrapolated to $1873 \mathrm{~K}$ to reexamine Chipman et al.'s reported data. They reported $\gamma_{\mathrm{Al}}^{0}, \varepsilon_{\mathrm{Al}}^{\mathrm{Al}}$ and $e_{\mathrm{Al}}^{\mathrm{Al}}$ values in liquid iron as $0.063,5.3$ and 0.043 at $1873 \mathrm{~K}$, respectively. Wooley and Elliott ${ }^{4}$ measured the partial molar heats of solution of aluminum at $1873 \mathrm{~K}$ in the high-temperature solution calorimeter in the range of $0<x_{\mathrm{Al}}<0.56$ for the $\mathrm{Fe}-$ $\mathrm{Al}$ system, They reported $\gamma_{\mathrm{Al}}^{0}, \varepsilon_{\mathrm{Al}}^{\mathrm{Al}}$ and $e_{\mathrm{Al}}^{\mathrm{Al}}$ values as 0.061 , 5.6 and 0.045 at $1873 \mathrm{~K}$, respectively. Coskun and Elliott ${ }^{5)}$ measured the activity of aluminum in liquid $\mathrm{Fe}-\mathrm{Al}$ system by an improved version of the transportation method in which the metallic vapor was collected by its solution in 
a metallic condenser, and proposed the equation $\log \gamma_{\mathrm{Al}}=$ $-3.0\left(1-x_{\mathrm{Al}}\right)^{2}$. Using Knudsen cell-mass spectrometry, Belton and Fruhan ${ }^{6}$ directly measured the activity of aluminum in liquid $\mathrm{Fe}-\mathrm{Al}$ alloys up to 20.29 mass\% $\mathrm{Al}$ at $1873 \mathrm{~K}$. Ichise et $a l^{7)}$ also used the same experimental technique to determine the activity of aluminum in liquid $\mathrm{Fe}-\mathrm{Al}$ alloys up to $8.21 \mathrm{mass} \% \mathrm{Al}$ in the temperature range from $1673 \mathrm{~K}$ to $1873 \mathrm{~K}$. They reported the values of $\gamma_{\mathrm{Al}}^{0}, \varepsilon_{\mathrm{Al}}^{\mathrm{Al}}, \gamma_{\mathrm{Fe}}^{0}$ and $\varepsilon_{\mathrm{Fe}}^{\mathrm{Fe}}$ in liquid iron as $0.049,6.4,0.017$ and 8.2 at $1873 \mathrm{~K}$, respectively. Jacobson and Mehrotra ${ }^{8)}$ determined the activities of $\mathrm{Fe}$ and $\mathrm{Al}$ in $\mathrm{Fe}-\mathrm{Al}$ alloys at $1573 \mathrm{~K}$ using the ion-currentratio technique in a high-temperature Knudsen cell-mass spectrometry, and reported the values of $\gamma_{\mathrm{Al}}^{0}$ and $\gamma_{\mathrm{Fe}}^{0}$ at 1573 $\mathrm{K}$ as 0.016 and 0.019 . In 2007, Kim et al. ${ }^{9)}$ investigated the thermodynamics of aluminum in liquid iron in the temperature range of $1873 \mathrm{~K}-1973 \mathrm{~K}$ and reported the values of $\gamma_{\mathrm{Al}}^{0}$ as $0.066,0.069$ and 0.071 at $1873 \mathrm{~K}, 1923 \mathrm{~K}$ and $1973 \mathrm{~K}$. Recently, Zaitsev et al. ${ }^{10)}$ reported that three associative molecules as $\mathrm{FeAl}, \mathrm{FeAl}_{2}$, and $\mathrm{Fe}_{2} \mathrm{Al}_{5}$ could exist in $\mathrm{Fe}-\mathrm{Al}$ binary melts based on the experimental results using Knudsen cell-mass spectrometer and an integral variant of the effusion method under the condition of super high oil-free vacuum. But after checking previous literatures and phase diagram of $\mathrm{Fe}-\mathrm{Al}$ binary system, $\mathrm{Zhang}^{11)}$ proposed that five molecules as $\mathrm{Fe}_{3} \mathrm{Al}$, $\mathrm{FeAl}, \mathrm{FeAl}_{2}, \mathrm{Fe}_{2} \mathrm{Al}_{5}$ and $\mathrm{FeAl}_{6}$ could exist in $\mathrm{Fe}-$ Al binary melts. Other researchers ${ }^{12-17,24-26)}$ have reached the similar viewpoint for metallic melts that molecules can exist in metallic melts besides atoms. Several attempts ${ }^{24-26)}$ can well describe the thermodynamic properties of metallic melts on the concept of ionic or molecular constituents associated with artificial parameters, and most of the regressed artificial parameters were obtained by experimental results. ${ }^{20)}$

Although various experimental technique were adopted to measure the activity of $\mathrm{Al}$ and $\mathrm{Fe}$ in liquid $\mathrm{Fe}-\mathrm{Al}$ alloys, to the knowledge of the present authors, no prediction model was established to predict or evaluate the activity of $\mathrm{Al}$ and $\mathrm{Fe}$ in liquid $\mathrm{Fe}-\mathrm{Al}$ alloys. In this study, the AMCT $-N_{i}$ thermodynamic model for calculating the mass action concentrations $N_{i}$ of structural units in Fe-Al binary melts in the temperature range from $1573 \mathrm{~K}$ to $1873 \mathrm{~K}$ has been developed without any regressed parameters. The reported activities of $\mathrm{Al}$ and $\mathrm{Fe}$ by different researchers in a temperature range from $1573 \mathrm{~K}$ to $1873 \mathrm{~K}$ were chosen as evaluation criteria to verify the accuracy of the developed AMCT- $N_{i}$ thermodynamic model for $\mathrm{Fe}-\mathrm{Al}$ binary melts. It should be emphasized that the reported activities of $\mathrm{Al}$ and $\mathrm{Fe}$ are relative to pure liquid $\mathrm{Al}(\mathrm{l})$ and $\mathrm{Fe}(\mathrm{l})$ as standard state, i.e., $a_{\mathrm{R}, \mathrm{Al}}$ of $\mathrm{Al}$ and $a_{\mathrm{R}, \mathrm{Fe}}$ of Fe. The ultimate aim of this study is to pave the way for developing a universal AMCT $-N_{i}$ thermodynamic model for representing the reaction abilities of structural units in any binary metallic melts by the calculated mass action concentrations $N_{i}$ of structural units in the binary melts.

\section{AMCT- $N_{i}$ Thermodynamic Model for Fe-Al Binary Melts}

\subsection{Hypotheses}

It has been briefly demonstrated in Section 1 that atoms of $\mathrm{Fe}$ and $\mathrm{Al}$, and molecules as $\mathrm{Fe}_{3} \mathrm{Al}, \mathrm{FeAl}, \mathrm{FeAl}_{2}, \mathrm{Fe}_{2} \mathrm{Al}_{5}$ and $\mathrm{FeAl}_{6}$ can coexist in $\mathrm{Fe}-\mathrm{Al}$ binary melts. Therefore, the atom-molecule coexistence theory, i.e., AMCT, can be applied to describe the structural characteristics of $\mathrm{Fe}-\mathrm{Al}$ binary melts. The hypotheses of the developed AMCT $-N_{i}$ model for $\mathrm{Fe}-\mathrm{Al}$ binary melts can be briefly summarized as follows: 1) the $\mathrm{Fe}-\mathrm{Al}$ binary melts at elevated temperature are composed of seven structural units including two atoms as $\mathrm{Fe}$ and $\mathrm{Al}$ as well as five molecules as $\mathrm{Fe}_{3} \mathrm{Al}, \mathrm{FeAl}$, $\mathrm{FeAl}_{2}, \mathrm{Fe}_{2} \mathrm{Al}_{5}$ and $\mathrm{FeAl}_{6}$ according to the phase diagram of $\mathrm{Fe}-\mathrm{Al}$ binary melts ${ }^{18,21)}$ and viewpoints described in Section 1 from the literature; ${ }^{11}$ 2) each structural unit occupies its independent position in $\mathrm{Fe}-\mathrm{Al}$ binary melts; 3 ) the elements of both $\mathrm{Fe}$ and $\mathrm{Al}$ in $\mathrm{Fe}-\mathrm{Al}$ binary melts will take part in reactions of forming five molecules as $\mathrm{Fe}_{3} \mathrm{Al}, \mathrm{FeAl}, \mathrm{FeAl}_{2}$, $\mathrm{Fe}_{2} \mathrm{Al}_{5}$ and $\mathrm{FeAl}_{6}$ in the form of atoms; 4) the reactions of forming five molecules as $\mathrm{Fe}_{3} \mathrm{Al}, \mathrm{FeAl}, \mathrm{FeAl}_{2}, \mathrm{Fe}_{2} \mathrm{Al}_{5}$ and $\mathrm{FeAl}_{6}$ are under the chemical dynamic equilibrium between the simple atoms of both $\mathrm{Fe}$ and $\mathrm{Al} ; 5$ ) five structural units in $\mathrm{Fe}-\mathrm{Al}$ binary melts as $\mathrm{Fe}_{3} \mathrm{Al}, \mathrm{FeAl}, \mathrm{FeAl}_{2}, \mathrm{Fe}_{2} \mathrm{Al}_{5}$ and $\mathrm{FeAl}_{6}$ bear the structural continuity in the investigated composition range; 6) the chemical reactions of forming five molecules as $\mathrm{Fe}_{3} \mathrm{Al}$, $\mathrm{FeAl}, \mathrm{FeAl}_{2}, \mathrm{Fe}_{2} \mathrm{Al}_{5}$ and $\mathrm{FeAl}_{6}$ from $\mathrm{Fe}$ and $\mathrm{Al}$ obey the mass action law.

\subsection{Establishment of AMCT-N $N_{i}$ Thermodynamic Model for Fe-Al Binary Melts}

The mole numbers of two atoms as $\mathrm{Fe}$ and $\mathrm{Al}$ before equilibrium or before forming five molecules as $\mathrm{Fe}_{3} \mathrm{Al}, \mathrm{FeAl}$, $\mathrm{FeAl}_{2}, \mathrm{Fe}_{2} \mathrm{Al}_{5}$ and $\mathrm{FeAl}_{6}$ in $100-\mathrm{g} \mathrm{Fe}-\mathrm{Al}$ binary melts were assigned as $b_{1}=n_{\mathrm{Fe}}^{0}$ and $b_{2}=n_{\mathrm{Al}}^{0}$ to represent the chemical composition of $\mathrm{Fe}-\mathrm{Al}$ binary melts. Two atoms of $\mathrm{Fe}$ and $\mathrm{Al}$ as well as five molecules of $\mathrm{Fe}_{3} \mathrm{Al}, \mathrm{FeAl}, \mathrm{FeAl}_{2}, \mathrm{Fe}_{2} \mathrm{Al}_{5}$ and $\mathrm{FeAl}_{6}$ in $\mathrm{Fe}-\mathrm{Al}$ binary melts at the studied temperatures were summarized and assigned with exclusive numbers in Table 1. The defined equilibrium mole numbers $n_{i}$ of all above-mentioned five structural units as $\mathrm{Fe}_{3} \mathrm{Al}$, $\mathrm{FeAl}$, $\mathrm{FeAl}_{2}, \mathrm{Fe}_{2} \mathrm{Al}_{5}$ and $\mathrm{FeAl}_{6}$ in $100-\mathrm{g} \mathrm{Fe}-\mathrm{Al}$ binary melts at the studied temperatures were also listed in Table 1. The total equilibrium mole number $\Sigma n_{i}$ of all seven structural units in

Table 1. Expressions of structural units as atoms or molecules, their equilibrium mole numbers $n_{i}$ and mass action concentrations $N_{i}$ in $100-\mathrm{g} \mathrm{Fe}-\mathrm{Al}$ binary melts based on the AMCT.

\begin{tabular}{|c|c|c|c|c|}
\hline Item & $\begin{array}{c}\text { Structural } \\
\text { units as atoms } \\
\text { or molecules }\end{array}$ & $\begin{array}{l}\text { No. of } \\
\text { structural } \\
\text { units }\end{array}$ & $\begin{array}{l}\text { Mole numbers } \\
\text { of structural } \\
\text { units (mol) }\end{array}$ & $\begin{array}{c}\text { Mass action } \\
\text { concentrations of } \\
\text { structural units } N_{i}(-)\end{array}$ \\
\hline \multirow{2}{*}{$\begin{array}{l}\text { Atom } \\
\text { (2) }\end{array}$} & $\mathrm{Fe}$ & 1 & $n_{1}=n_{\mathrm{Fe}}$ & $N_{1}=\frac{n_{1}}{\sum n_{i}}=N_{\mathrm{Fe}}$ \\
\hline & Al & 2 & $n_{2}=n_{\mathrm{Al}}$ & $N_{2}=\frac{n_{2}}{\Sigma n_{i}}=N_{\mathrm{Al}}$ \\
\hline \multirow{5}{*}{$\begin{array}{l}\text { Molecules } \\
\text { (5) }\end{array}$} & $\mathrm{Fe}_{3} \mathrm{Al}$ & c1 & $n_{\mathrm{cl}}=n_{\mathrm{Fe}_{3} \mathrm{Al}}$ & $N_{\mathrm{cl}}=\frac{n_{\mathrm{cl}}}{\sum n_{i}}=N_{\mathrm{Fe}_{3} \mathrm{Al}}$ \\
\hline & $\mathrm{FeAl}$ & c2 & $n_{\mathrm{c} 2}=n_{\mathrm{FeAl}}$ & $N_{\mathrm{c} 2}=\frac{n_{\mathrm{c} 2}}{\sum n_{i}}=N_{\mathrm{FeA} 1}$ \\
\hline & $\mathrm{FeAl}_{2}$ & c3 & $n_{\mathrm{c} 3}=n_{\mathrm{FeAl}_{2}}$ & $N_{\mathrm{c} 3}=\frac{n_{\mathrm{c} 3}}{\Sigma n_{i}}=N_{\mathrm{FeAl}_{2}}$ \\
\hline & $\mathrm{Fe}_{2} \mathrm{Al}_{5}$ & c4 & $n_{\mathrm{c} 4}=n_{\mathrm{Fe}_{2} \mathrm{Al}_{5}}$ & $N_{\mathrm{c} 4}=\frac{n_{\mathrm{c} 4}}{\sum n_{i}}=N_{\mathrm{Fe}_{2} \mathrm{Al}_{5}}$ \\
\hline & $\mathrm{FeAl}_{6}$ & $\mathrm{c} 5$ & $n_{\mathrm{c} 5}=n_{\mathrm{FeAl}_{6}}$ & $N_{\mathrm{c} 5}=\frac{n_{\mathrm{c} 5}}{\Sigma n_{i}}=N_{\mathrm{FeAl}_{6}}$ \\
\hline
\end{tabular}


100-g Fe-Al binary melts can be expressed as

$$
\begin{aligned}
\Sigma n_{i} & =n_{1}+n_{2}+n_{\mathrm{c} 1}+n_{\mathrm{c} 2}+n_{\mathrm{c} 3}+n_{\mathrm{c} 4}+n_{\mathrm{c} 5} \\
& =n_{\mathrm{Fe}}+n_{\mathrm{Al}}+n_{\mathrm{Fe}_{3} \mathrm{Al}}+n_{\mathrm{FeAl}}+n_{\mathrm{FeAl}_{2}}+n_{\mathrm{Fe}_{2} \mathrm{Al}_{5}}+n_{\mathrm{FeAl}_{6}}
\end{aligned}
$$

According to the definition of mass action concentrations $N_{i}$ for structural units based on the $\mathrm{AMCT}^{11,18-20)}$ for metallic melts or the $\mathrm{IMCT}^{22,23)}$ for metallurgical slags, the mass action concentrations $N_{i}$ of structural units $i$ in metallic melts can be calculated by

$$
N_{i}=\frac{n_{i}}{\Sigma n_{i}} \quad(-)
$$

The chemical reaction formulas of forming five molecules as $\mathrm{Fe}_{3} \mathrm{Al}, \mathrm{FeAl}, \mathrm{FeAl}_{2}, \mathrm{Fe}_{2} \mathrm{Al}_{5}$ and $\mathrm{FeAl}_{6}$, the related standard reaction equilibrium constants $K_{\mathrm{c} i}^{\Theta, \mathrm{R}}$ relative to pure liquid matter as standard state, and the representations of mass action concentrations $N_{\mathrm{c} i}$ of five molecules as $\mathrm{Fe}_{3} \mathrm{Al}, \mathrm{FeAl}, \mathrm{FeAl}_{2}, \mathrm{Fe}_{2} \mathrm{Al}_{5}$ and $\mathrm{FeAl}_{6}$ using $K_{\mathrm{c} i}^{\Theta}, \mathrm{R}, N_{1}\left(N_{\mathrm{Fe}}\right)$ and $N_{2}\left(N_{\mathrm{Al}}\right)$ based on the mass action law were summarized in Table 2.

The mass conservation equations of two atoms as $\mathrm{Fe}$ and $\mathrm{Al}$ in 100-g Fe-Al binary melts can be established based on the above-mentioned definitions ${ }^{11,18-20,22,23)}$ of $n_{i}, N_{i}$, and $\Sigma n_{i}$ as follows

$$
\begin{aligned}
b_{1} & =\left(N_{1}+3 N_{\mathrm{c} 1}+N_{\mathrm{c} 2}+N_{\mathrm{c} 3}+2 N_{\mathrm{c} 4}+N_{\mathrm{c} 5}\right) \Sigma n_{i} \\
& =\left(N_{1}+3 K_{\mathrm{c} 1}^{\Theta, \mathrm{R}} N_{1}^{3} N_{2}+K_{\mathrm{c} 2}^{\Theta, \mathrm{R}} N_{1} N_{2}\right. \\
& \left.+K_{\mathrm{c} 3}^{\Theta, \mathrm{R}} N_{1} N_{2}^{2}+2 K_{\mathrm{c} 4}^{\Theta, \mathrm{R}} N_{1}^{2} N_{2}^{5}+K_{\mathrm{c} 5}^{\Theta, \mathrm{R}} N_{1} N_{2}^{6}\right) \\
& =\left(N_{\mathrm{Fe}}+3 K_{\mathrm{c} 1}^{\Theta, \mathrm{R}} N_{\mathrm{Fe}}^{3} N_{\mathrm{Al}}+K_{\mathrm{c} 2}^{\Theta, \mathrm{R}} N_{\mathrm{Fe}} N_{\mathrm{Al}}+K_{\mathrm{c} 3, \mathrm{R}} N_{\mathrm{Fe}} N_{\mathrm{A} 1}^{2}\right. \\
& \left.+2 K_{\mathrm{c} 4}^{\Theta, \mathrm{R}} N_{\mathrm{Fe}}^{2} N_{\mathrm{A} 1}^{5}+K_{\mathrm{c} 5}^{\Theta, \mathrm{R}} N_{\mathrm{Fe}} N_{\mathrm{Al}}^{6}\right) \Sigma n_{i}=n_{\mathrm{Fe}}^{0}
\end{aligned}
$$

$$
\begin{aligned}
b_{2} & =\left(N_{2}+N_{\mathrm{c} 1}+N_{\mathrm{c} 2}+2 N_{\mathrm{c} 3}+5 N_{\mathrm{c} 4}+6 N_{\mathrm{c} 5}\right) \Sigma n_{i} \\
& =\left(N_{2}+K_{\mathrm{c} 1}^{\Theta, \mathrm{R}} N_{1}^{3} N_{2}+K_{\mathrm{c} 2}^{\Theta, \mathrm{R}} N_{1} N_{2}+2 K_{\mathrm{c} 3}^{\Theta, \mathrm{R}} N_{1} N_{2}^{2}\right. \\
& \left.+5 K_{\mathrm{c} 4}^{\Theta, \mathrm{R}} N_{1}^{2} N_{2}^{5}+6 K_{\mathrm{c} 5}^{\Theta, \mathrm{R}} N_{1} N_{2}^{6}\right) \Sigma n_{i} \\
& =\left(N_{\mathrm{Al}}+K_{\mathrm{c} 1}^{\Theta, \mathrm{R}} N_{\mathrm{Fe}}^{3} N_{\mathrm{Al}}+K_{\mathrm{c} 2}^{\Theta, \mathrm{R}} N_{\mathrm{Fe}} N_{\mathrm{Al}}+2 K_{\mathrm{c} 3}^{\Theta, \mathrm{R}} N_{\mathrm{Fe}} N_{\mathrm{Al}}^{2}\right. \\
& \left.+5 K_{\mathrm{c} 4}^{\Theta, \mathrm{R}} N_{\mathrm{Fe}}^{2} N_{\mathrm{Al}}^{5}+6 K_{\mathrm{c} 5}^{\Theta, \mathrm{R}} N_{\mathrm{Fe}} N_{\mathrm{Al}}^{6}\right) \Sigma n_{i}=n_{\mathrm{Al}}^{0}
\end{aligned}
$$

According to the principle that the sum of mole fraction of all structural units in a fixed amount of metallic melts under equilibrium condition is equal to unity as 1 , the following equation can be established

$$
\begin{aligned}
& N_{1}+N_{2}+N_{\mathrm{c} 1}+N_{\mathrm{c} 2}+N_{\mathrm{c} 3}+N_{\mathrm{c} 4}+N_{\mathrm{c} 5} \\
& =N_{\mathrm{Fe}}+N_{\mathrm{Al}}+N_{\mathrm{Fe}_{3} \mathrm{Al}}+N_{\mathrm{FeAl}}+N_{\mathrm{FeAl}_{2}}+N_{\mathrm{Fe}_{2} \mathrm{Al}_{5}}+N_{\mathrm{FeAl}_{6}}=1.0
\end{aligned}
$$

The governing equations of the developed AMCT $-N_{i}$ thermodynamic model for calculating the mass action concentrations $N_{i}$ of structural units in Fe-Al binary melts are comprised by the equation group of Eqs. (3) and (4). Obviously, there are three unknown parameters as $N_{1}\left(N_{\mathrm{Fe}}\right), N_{2}\left(N_{\mathrm{Al}}\right)$, and $\Sigma n_{i}$ with three independent equations in the established equation group of Eqs. (3) and (4). The unique solution of $N_{i}, \Sigma n_{i}$, and $n_{i}$ can be calculated by solving the algebraic equation group of Eqs. (3) and (4) through combining with the definition of $N_{i}$ in Eq. (2) after knowing the values of $K_{\mathrm{cl}}^{\Theta, \mathrm{R}}\left(K_{\mathrm{Fe}_{3} \mathrm{Al}}^{\Theta, \mathrm{R}}\right), K_{\mathrm{c} 2}^{\Theta, \mathrm{R}}\left(K_{\mathrm{FeAl}}^{\Theta, \mathrm{R}}\right), K_{\mathrm{c} 3}^{\Theta, \mathrm{R}}\left(K_{\mathrm{FeAl}_{2}}^{\Theta, \mathrm{R}}\right), K_{\mathrm{c} 4}^{\Theta, \mathrm{R}}\left(K_{\mathrm{Fe}_{2} \mathrm{Al}_{5}}^{\Theta}\right)$, and $K_{\mathrm{c} 5}^{\Theta, \mathrm{R}}\left(K_{\mathrm{FeAl}}^{\Theta, \mathrm{R}}\right)$.

The standard equilibrium constant $K_{\mathrm{c} i}^{\Theta, \mathrm{R}}$ of reactions for five molecules as $\mathrm{Fe}_{3} \mathrm{Al}, \mathrm{FeAl}, \mathrm{FeAl}_{2}, \mathrm{Fe}_{2} \mathrm{Al}_{5}$ and $\mathrm{FeAl}_{6}$ in $\mathrm{Fe}-\mathrm{Al}$ binary melts at a fixed temperature can be calculated based on the obtained standard molar Gibbs free energy change $\Delta_{\mathrm{r}} G_{\mathrm{m}, \mathrm{c} i}^{\Theta, \mathrm{R}}$ of the same reaction from the mass action law as $\Delta_{\mathrm{r}} G_{\mathrm{m}, \mathrm{c} i}^{\Theta, \mathrm{R}}=-R T \ln K_{\mathrm{c} i}^{\Theta, \mathrm{R}}$ based on $K_{\mathrm{c} i}^{\Theta, \mathrm{R}}=a_{\mathrm{Fe}_{x} \mathrm{Al}_{y}} /\left(a_{\mathrm{Fe}}^{x} a_{\mathrm{Al}}^{y}\right)$. Meanwhile, the standard molar Gibbs free energy changes $\Delta_{\mathrm{r}} G_{\mathrm{m}, \mathrm{R} i}^{\Theta}$ of reactions for forming $\mathrm{Fe}_{3} \mathrm{Al}, \mathrm{FeAl}, \mathrm{FeAl}_{2}, \mathrm{Fe}_{2} \mathrm{Al}_{5}$ and $\mathrm{FeAl}_{6}$ from $\mathrm{Fe}$ and $\mathrm{Al}$ have been reported by $\mathrm{Zhang}{ }^{11,18)}$ relative to pure liquid matter as standard states as follows

$$
\begin{aligned}
& 3[\mathrm{Fe}]+[\mathrm{Al}]=\left[\mathrm{Fe}_{3} \mathrm{Al}\right] \\
& \Delta_{\mathrm{r}} G_{\mathrm{m}, \mathrm{Fe}_{3} \mathrm{Al}}^{\Theta}=-R T \ln \left(\frac{a_{\mathrm{R}, \mathrm{Fe}_{3} \mathrm{Al}}}{a_{\mathrm{R}, \mathrm{Fe}}^{3} a_{\mathrm{R}, \mathrm{Al}}}\right)=-120586.85+48.61 T
\end{aligned}
$$

$$
\begin{aligned}
& {[\mathrm{Fe}]+[\mathrm{Al}]=[\mathrm{FeAl}]} \\
& \Delta_{\mathrm{r}} G_{\mathrm{m}, \mathrm{FeAl}}^{\Theta, \mathrm{R}}=-R T \ln \left(\frac{a_{\mathrm{R}, \mathrm{FeAl}}}{a_{\mathrm{R}, \mathrm{Fe}} a_{\mathrm{R}, \mathrm{Al}}}\right)=-47813.257+7.8937
\end{aligned}
$$

$$
[\mathrm{Fe}]+2[\mathrm{Al}]=\left[\mathrm{FeAl}_{2}\right]
$$$$
\Delta_{\mathrm{r}} G_{\mathrm{m}, \mathrm{FeAl}_{2}}^{\Theta, \mathrm{R}}=-R T \ln \left(\frac{a_{\mathrm{R}, \mathrm{FeAl}_{2}}}{a_{\mathrm{R}, \mathrm{Fe}} a_{\mathrm{R}, \mathrm{Al}}^{2}}\right)=130186.64-84.582 T
$$

Table 2. Chemical reaction formulas of formed molecules, their standard equilibrium constants $K_{\mathrm{c} i}^{\Theta, \mathrm{R}}$, and mass action concentrations $N_{\text {ci }}$ of formed molecules in $\mathrm{Fe}-\mathrm{Al}$ binary melts based on the AMCT.

\begin{tabular}{ccc}
\hline Reactions & $K_{\mathrm{c} i}^{\Theta, \mathrm{R}}(-)$ & $N_{\mathrm{ci}}(-)$ \\
\hline $3[\mathrm{Fe}]+[\mathrm{Al}]=[\mathrm{Fe} 3 \mathrm{Al}]$ & $K_{\mathrm{cl}}^{\Theta, \mathrm{R}}=\frac{N_{\mathrm{c} 1}}{N_{1}^{3} N_{2}}=\frac{N_{\mathrm{Fe}_{3} \mathrm{Al}}}{N_{\mathrm{Fe}}^{3} N_{\mathrm{Al}}}$ & $N_{\mathrm{cl}}=K_{\mathrm{c} 1}^{\Theta, \mathrm{R}} N_{1}^{3} N_{2}=K_{\left[\mathrm{Fe}_{3} \mathrm{All}\right.}^{\Theta, \mathrm{R}} N_{\mathrm{Fe}}^{3} N_{\mathrm{Al}}$ \\
{$[\mathrm{Fe}]+[\mathrm{Al}]=[\mathrm{FeAl}]$} & $K_{\mathrm{c} 2}^{\Theta, \mathrm{R}}=\frac{N_{\mathrm{c} 2}}{N_{1} N_{2}}=\frac{N_{\mathrm{FeAl}}}{N_{\mathrm{Fe}} N_{\mathrm{Al}}}$ & $N_{\mathrm{c} 2}=K_{\mathrm{c} 2}^{\Theta, \mathrm{R}} N_{1} N_{2}=K_{[\mathrm{FeAl}]}^{\Theta, \mathrm{R}} N_{\mathrm{Fe}} N_{\mathrm{Al}}$ \\
{$[\mathrm{Fe}]+2[\mathrm{Al}]=[\mathrm{FeAl}]$} & $K_{\mathrm{c} 3}^{\Theta, \mathrm{R}}=\frac{N_{\mathrm{c} 2}}{N_{1} N_{2}^{2}}=\frac{N_{\mathrm{FeAl}_{2}}}{N_{\mathrm{Fe}} N_{\mathrm{Al}}^{2}}$ & $N_{\mathrm{c} 3}=K_{\mathrm{c} 3}^{\Theta, \mathrm{R}} N_{1} N_{2}^{2}=K_{\left[\mathrm{FeAl}_{2}\right]}^{\Theta, \mathrm{R}} N_{\mathrm{Fe}} N_{\mathrm{Al}}^{2}$ \\
{$[\mathrm{Fe}]+[\mathrm{Al}]=\left[\mathrm{Fe}_{2} \mathrm{~A} l_{5}\right]$} & $K_{\mathrm{c} 4}^{\Theta, \mathrm{R}}=\frac{N_{\mathrm{c} 4}}{N_{1}^{2} N_{2}^{5}}=\frac{N_{\mathrm{Fe}_{2} \mathrm{Al}}}{N_{\mathrm{Fe}}^{2} N_{\mathrm{Al}}^{5}}$ & $N_{\mathrm{c} 4}=K_{\mathrm{c} 4}^{\Theta, \mathrm{R}} N_{1}^{2} N_{2}^{5}=K_{\left[\mathrm{Fe}_{2} \mathrm{Al}_{5}\right]}^{\Theta, \mathrm{R}} N_{\mathrm{Fe}}^{2} N_{\mathrm{Al}}^{5}$ \\
{$[\mathrm{Fe}]+6[\mathrm{Al}]=\left[\mathrm{FeAl}_{6}\right]$} & $K_{\mathrm{c} 5}^{\Theta, \mathrm{R}}=\frac{N_{\mathrm{c} 5}}{N_{1} N_{2}^{6}}=\frac{N_{\mathrm{FeAl}_{6}}}{N_{\mathrm{Fe}_{\mathrm{Al}}} N_{\mathrm{Ac}}^{6}}$ & $N_{\mathrm{c} 5}=K_{\mathrm{c} 5}^{\Theta, \mathrm{R}} N_{1} N_{2}^{6}=K_{\left[\mathrm{FeA}_{6}\right]}^{\Theta, \mathrm{R}} N_{\mathrm{Fe}} N_{\mathrm{Al}}^{6}$ \\
\hline
\end{tabular}




$$
\begin{aligned}
& 2[\mathrm{Fe}]+5[\mathrm{Al}]=\left[\mathrm{Fe}_{2} \mathrm{Al}_{5}\right] \\
& \Delta_{\mathrm{r}} G_{\mathrm{m}, \mathrm{R}_{2} \mathrm{Al}_{5}}^{\Theta}=-R T \ln \left(\frac{a_{\mathrm{R}, \mathrm{Fe}_{2} \mathrm{Al}_{5}}}{a_{\mathrm{R}, \mathrm{Fe}}^{2} a_{\mathrm{R}, \mathrm{Al}}^{5}}\right)=-165372.213+43.05 T
\end{aligned}
$$

$$
\begin{aligned}
& {[\mathrm{Fe}]+6[\mathrm{Al}]=\left[\mathrm{FeAl}_{6}\right]} \\
& \Delta_{\mathrm{r}} G_{\mathrm{m}, \mathrm{FeA}}^{\Theta, \mathrm{R}}=-R T \ln \left(\frac{a_{\mathrm{R}, \mathrm{FeAl}_{6}}}{a_{\mathrm{R}, \mathrm{Fe}} a_{\mathrm{R}, \mathrm{Al}}^{6}}\right)=-14710.17-18.712 T
\end{aligned}
$$

\section{Results and Discussion for Calculated Mass Action Concentrations $N_{i}$ of Structural Units in $\mathrm{Fe}-\mathrm{Al}$ Binary Melts}

3.1. Comparison between Calculated Mass Action Concentration $N_{\mathrm{Al}}$ of $\mathrm{Al}$ or $N_{\mathrm{Fe}}$ of $\mathrm{Fe}$ and Reported Activity $a_{\mathrm{R}, \mathrm{Al}}$ of Al or $a_{\mathrm{R}, \mathrm{Fe}}$ of Fe by Different Researchers

To improve the readability of this article, chemical composition of $\mathrm{Fe}-\mathrm{Al}$ binary melts, reported activity $a_{\mathrm{R}, \mathrm{Fe}}$ of $\mathrm{Fe}$ or $a_{\mathrm{R}, \mathrm{Al}}$ of $\mathrm{Al}$ in a temperature range from $1573 \mathrm{~K}$ to 1873 $\mathrm{K}$ by different investigators, ${ }^{5-8,21)}$ calculated mass action concentrations $N_{i}$ of seven structural units including Fe, $\mathrm{Al}$, $\mathrm{Fe}_{3} \mathrm{Al}, \mathrm{FeAl}, \mathrm{FeAl}_{2}, \mathrm{Fe}_{2} \mathrm{Al}_{5}$ and $\mathrm{FeAl}_{6}$, and calculated total equilibrium mole number $\Sigma n_{i}$ of structural units in $100-\mathrm{g}$ $\mathrm{Fe}-\mathrm{Al}$ binary melts were summarized in Table 3 .

The comparison between the calculated mass action concentration $N_{\mathrm{Al}}$ of $\mathrm{Al}$ and the reported activity $a_{\mathrm{R}, \mathrm{Al}}$ of $\mathrm{Al}$ by different researchers ${ }^{5-8,21)}$ relative to pure liquid $\mathrm{Al}(1)$ as standard state in Fe-Al binary melts with changing mole fraction $x_{\mathrm{Al}}$ of $\mathrm{Al}$ from 0 to 1 in a temperature range from $1573 \mathrm{~K}$ to $1873 \mathrm{~K}$ was illustrated in Fig. 1(a). The comparison between the calculated mass action concentration $N_{\mathrm{Fe}}$ of $\mathrm{Fe}$ and the reported activity $a_{\mathrm{R}, \mathrm{Fe}}$ of $\mathrm{Fe}$ by different researchers $^{6-8,21)}$ relative to pure liquid $\mathrm{Fe}(\mathrm{l})$ as standard state in $\mathrm{Fe}-\mathrm{Al}$ binary melts with changing mole fraction $x_{\mathrm{Fe}}$ of $\mathrm{Fe}$ from 0 to 1 in the same temperature range was also shown in Fig. 1(b). The calculated mass action concentration $N_{\mathrm{Al}}$ of $\mathrm{Al}$ has a very excellent agreement with the reported activity $a_{\mathrm{R}, \mathrm{Al}}$ of Al by different researchers ${ }^{5-8,21)}$ in $\mathrm{Fe}-\mathrm{Al}$ binary melts as shown in Fig. 1(a). Meanwhile, the calculated mass action concentration $N_{\mathrm{Fe}}$ of $\mathrm{Fe}$ in the full composition has a very good 1:1 corresponding relationship with the reported activity $a_{\mathrm{R}, \mathrm{Fe}}$ of $\mathrm{Fe}$ by different researchers ${ }^{6-8,21)}$ in $\mathrm{Fe}-\mathrm{Al}$ binary melts as shown in Fig. 1(b). Obviously, the calculated mass action concentration $N_{\mathrm{Al}}$ of $\mathrm{Al}$ or $N_{\mathrm{Fe}}$ of Fe can be successfully applied to substitute the reported activity $a_{\mathrm{R}, \mathrm{Al}}$ of Al or $a_{\mathrm{R}, \mathrm{Fe}}$ of Fe by different researchers ${ }^{5-8,21)}$ in $\mathrm{Fe}-\mathrm{Al}$ binary melts in the full composition range in a temperature range from $1573 \mathrm{~K}$ to $1873 \mathrm{~K}$.

\subsection{Determination of Raoultian Activity Coefficient} $\gamma_{\mathrm{Al}}^{0}$ of $\mathrm{Al}$ and $\gamma_{\mathrm{Fe}}^{0}$ of $\mathrm{Fe}$ from Calculated Mass Action Concentration $N_{\mathrm{Al}}$ of $\mathrm{Al}$ and $N_{\mathrm{Fe}}$ of $\mathrm{Fe}$ in $\mathrm{Fe}-$ Al Binary Melts

The good 1:1 corresponding relationship between the calculated mass action concentration $N_{\mathrm{Al}}$ of $\mathrm{Al}$ and the reported activity $a_{\mathrm{R}, \mathrm{Al}}$ of $\mathrm{Al}$ by previous researchers ${ }^{5-8,21)}$ in $\mathrm{Fe}-\mathrm{Al}$ binary melts as described in Fig. 1(a) shows that the calculated mass action concentration $N_{\mathrm{Al}}$ of $\mathrm{Al}$, like the measured activity $a_{\mathrm{R}, \mathrm{Al}}$ of Al, can be applied to determine the activity coefficient $\gamma_{\mathrm{Al}}$ of $\mathrm{Al}$ in Fe-Al binary melts as $\gamma_{\mathrm{Al}}=N_{\mathrm{Al}} / x_{\mathrm{Al}}$.

The mass action concentrations $N_{i}$ of seven structural units in $\mathrm{Fe}-\mathrm{Al}$ binary melts with changing mole fraction $x_{\mathrm{Al}}$ of $\mathrm{Al}$ from 0 to 0.005 at an interval of $x_{\mathrm{Al}}$ as 0.00005 at temperature of $1573 \mathrm{~K}, 1673 \mathrm{~K}, 1773 \mathrm{~K}$, and $1873 \mathrm{~K}$ have been calculated based on the developed AMCT $-N_{i}$ model for $\mathrm{Fe}-\mathrm{Al}$ binary melts.

The relationship between mole fraction $x_{\mathrm{Al}}$ of $\mathrm{Al}$ and the calculated activity coefficient of $\mathrm{Al}$ in natural logarithmic form $\ln \gamma_{\mathrm{Al}}$ in $\mathrm{Fe}-\mathrm{Al}$ binary melts with changing mole fraction $x_{\mathrm{Al}}$ of $\mathrm{Al}$ from 0 to 0.005 at an interval of $x_{\mathrm{Al}}$ as 0.00005 at temperatures of $1573 \mathrm{~K}, 1673 \mathrm{~K}, 1773 \mathrm{~K}$, and $1873 \mathrm{~K}$ was illustrated in Fig. 2(a), respectively. The corresponding relationships at the above-mentioned four temperatures can be expressed by the linear equations as follows

$$
\begin{aligned}
& \ln \gamma_{\mathrm{Al}}=-3.810+4.476 x_{\mathrm{Al}} \\
& 0<x_{\mathrm{Al}} \leq 0.005, T=1573 \mathrm{~K} \quad(-) \\
& \ln \gamma_{\mathrm{Al}}=-3.397+4.248 x_{\mathrm{Al}} \\
& 0<x_{\mathrm{Al}} \leq 0.005, T=1673 \mathrm{~K}(-) \\
& \ln \gamma_{\mathrm{Al}}=-3.056+4.011 x_{\mathrm{Al}} \\
& 0<x_{\mathrm{Al}} \leq 0.005, T=1773 \mathrm{~K}(-) \\
& \ln \gamma_{\mathrm{Al}}=-2.537+3.599 x_{\mathrm{Al}} \\
& 0<x_{\mathrm{Al}} \leq 0.005, T=1873 \mathrm{~K}(-)
\end{aligned}
$$

The relationship between mole fraction $x_{\mathrm{Fe}}$ of $\mathrm{Fe}$ and the calculated activity coefficient of $\mathrm{Fe}$ in natural logarithmic form $\ln \gamma_{\mathrm{Fe}}$ in $\mathrm{Fe}-\mathrm{Al}$ binary melts with changing mole fraction $x_{\mathrm{Fe}}$ of Fe from 0 to 0.005 at an interval of $x_{\mathrm{Fe}}$ as 0.00005 at temperatures of $1573 \mathrm{~K}, 1673 \mathrm{~K}, 1773 \mathrm{~K}$, and $1873 \mathrm{~K}$ was illustrated in Fig. 2(b), respectively. The corresponding relationship at the above-mentioned four temperatures can be expressed by the linear equations as follows

$$
\begin{aligned}
& \ln \gamma_{\mathrm{Fe}}=-3.837+6.701 x_{\mathrm{Fe}} \\
& 0<x_{\mathrm{Fe}} \leq 0.005, T=1573 \mathrm{~K}(-) \\
& \ln \gamma_{\mathrm{Fe}}=-3.753+7.627 x_{\mathrm{Fe}} \\
& 0<x_{\mathrm{Fe}} \leq 0.005, T=1673 \mathrm{~K} \quad(-) \\
& \ln \gamma_{\mathrm{Fe}}=-3.701+8.066 x_{\mathrm{Fe}} \\
& 0<x_{\mathrm{Fe}} \leq 0.005, T=1773 \mathrm{~K}(-) \\
& \ln \gamma_{\mathrm{Fe}}=-3.686+8.176 x_{\mathrm{Fe}} \\
& 0<x_{\mathrm{Fe}} \leq 0.005, T=1873 \mathrm{~K}(-)
\end{aligned}
$$

The Raoultian activity coefficient $\gamma_{\mathrm{Al}}^{0}$ of $\mathrm{Al}$ in the infinitely dilute $\mathrm{Fe}-\mathrm{Al}$ binary melts related with activity $a_{\mathrm{R}, \mathrm{Al}}$ of $\mathrm{Al}$ can be defined as the value of $\gamma_{\mathrm{Al}, x_{\mathrm{Al}} \rightarrow 0.0 \text {. Therefore, }}$ the intercepts of the linear functions in Eq. (10) and in Fig. 2(a) can be treated as the values of the Raoultian activity coefficient $\ln \gamma_{\mathrm{Al}}^{0}$ of $\mathrm{Al}$ in the infinitely dilute $\mathrm{Fe}-\mathrm{Al}$ binary melts at the above-mentioned four temperatures. The effect of temperature from $1573 \mathrm{~K}$ to $1873 \mathrm{~K}$ on the determined Raoultian activity coefficient in natural logarithmic form $\ln \gamma_{\mathrm{Al}}^{0}$ of $\mathrm{Al}$ in the infinitely dilute $\mathrm{Fe}-\mathrm{Al}$ binary melts was 
Table 3. Chemical composition of Fe-Al binary melts, reported activity $a_{\mathrm{R}, \mathrm{Fe}}$ of $\mathrm{Fe}$ or $a_{\mathrm{R}, \mathrm{Al}}$ of $\mathrm{Al}$ in a temperature range from $1573 \mathrm{~K}$ to $1873 \mathrm{~K}$ by different investigators, calculated mass action concentrations $N_{i}$ of seven structural units including $\mathrm{Fe}, \mathrm{Al}, \mathrm{Fe}_{3} \mathrm{Al}, \mathrm{FeAl}, \mathrm{FeAl}_{2}, \mathrm{Fe}_{2} \mathrm{Al}_{5}$ and $\mathrm{FeAl}_{6}$, and calculated total equilibrium mole number $\Sigma n_{i}$ of structural units in $100-\mathrm{g} \mathrm{Fe}-\mathrm{Al}$ binary melts based on the developed AMCT- $N_{i}$ thermodynamic model for $\mathrm{Fe}-$ Al binary melts.

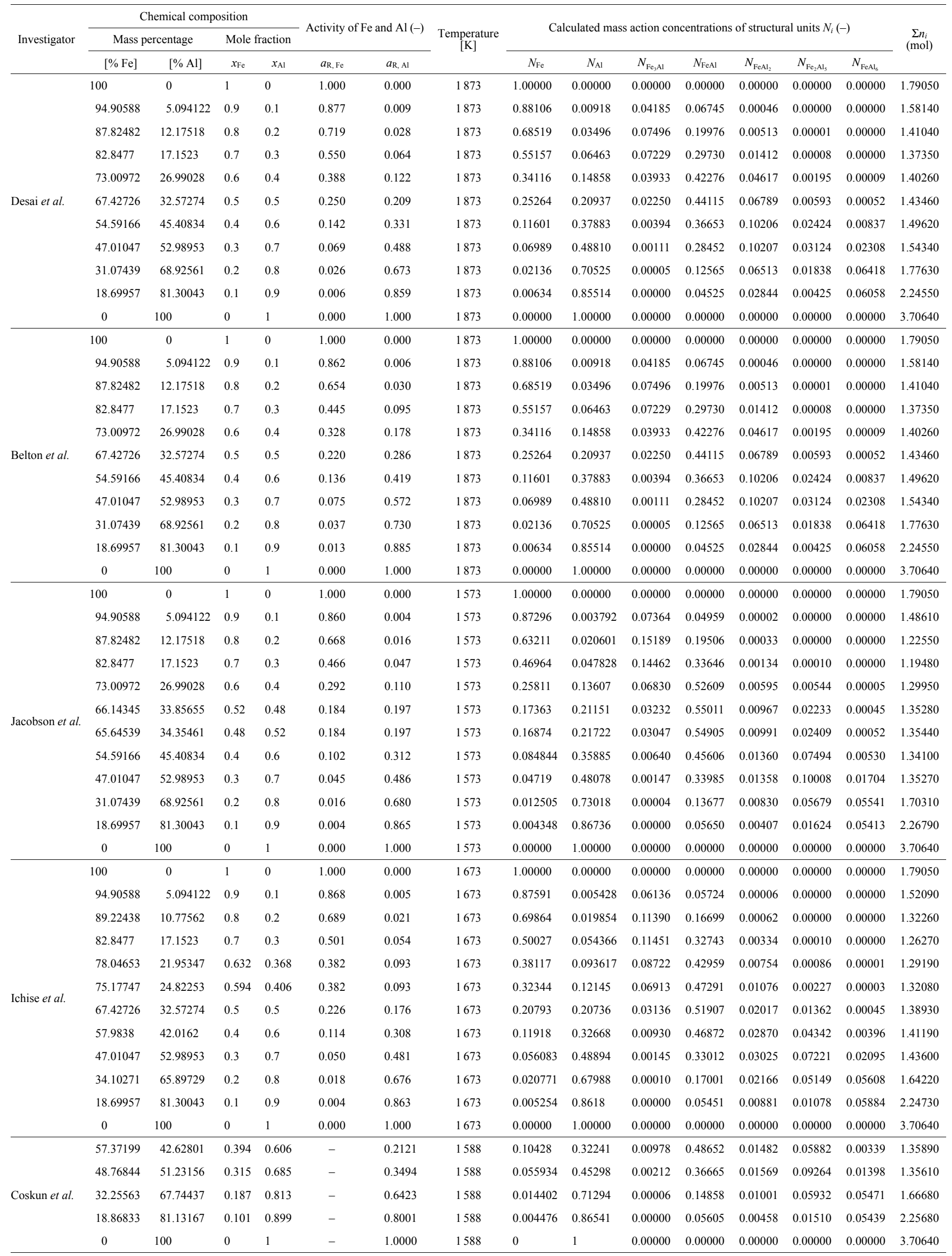



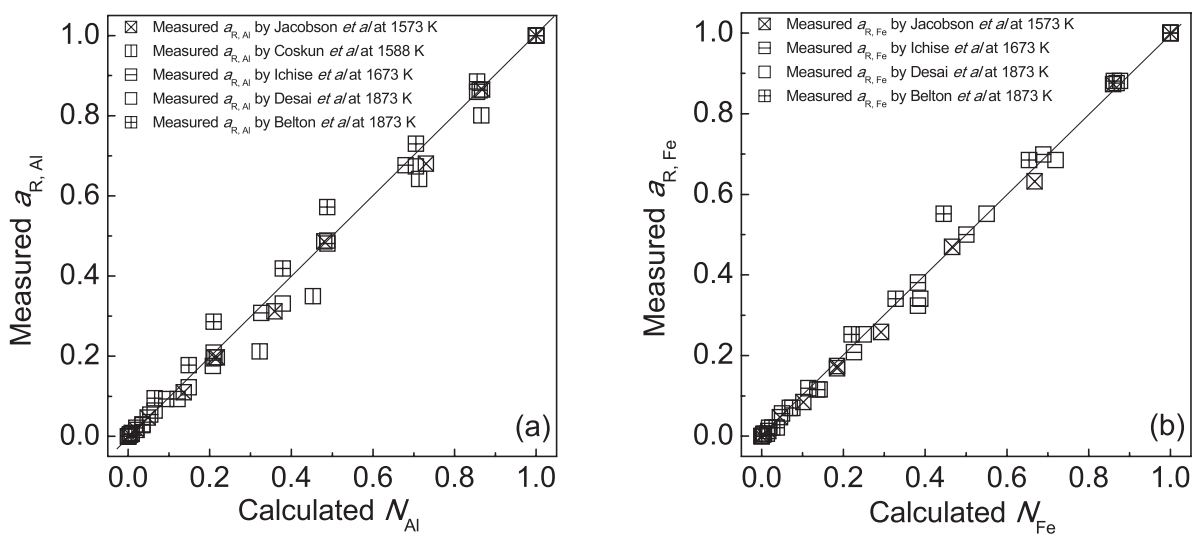

Fig. 1. Relationship between calculated mass action concentration $N_{\mathrm{Al}}$ of $\mathrm{Al}$ and reported activity $a_{\mathrm{R}, \mathrm{Al}}$ of $\mathrm{Al}$ by different researchers relative to pure liquid $\mathrm{Al}(1)$ as standard state $(a)$, and relationship between calculated mass action concentration $N_{\mathrm{Fe}}$ of $\mathrm{Fe}$ and reported activity $a_{\mathrm{R}, \mathrm{Fe}}$ of $\mathrm{Fe}$ by different researchers relative to pure liquid $\mathrm{Fe}(\mathrm{l})$ as standard state $(b)$ in Fe-Al binary melts in the temperature range from $1573 \mathrm{~K}$ to $1873 \mathrm{~K}$, respectively.
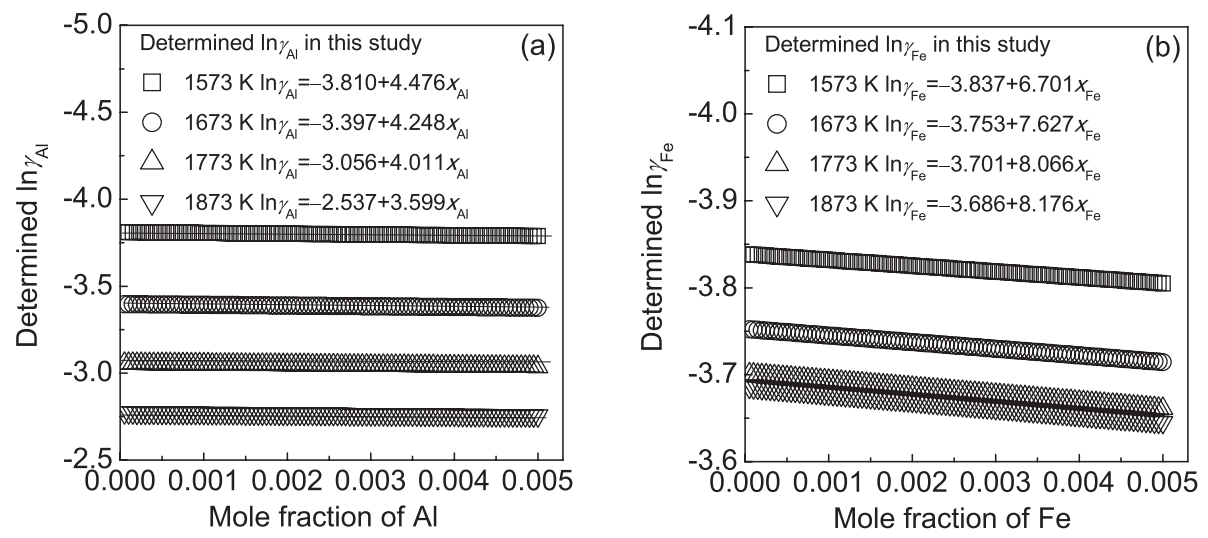

Fig. 2. Relationship between mole fraction $x_{\mathrm{Al}}$ of $\mathrm{Al}$ and calculated activity coefficient of $\mathrm{Al}$ in logarithmic form $\ln \gamma_{\mathrm{Al}}(a)$, and relationship between mole fraction $x_{\mathrm{Fe}}$ of $\mathrm{Fe}$ and calculated activity coefficient of Fe in logarithmic form $\ln \gamma_{\mathrm{Fe}}$ in Fe-Al binary melt at temperatures of $1573 \mathrm{~K}, 1673 \mathrm{~K}, 1773 \mathrm{~K}$, and $1873 \mathrm{~K}$, respectively.
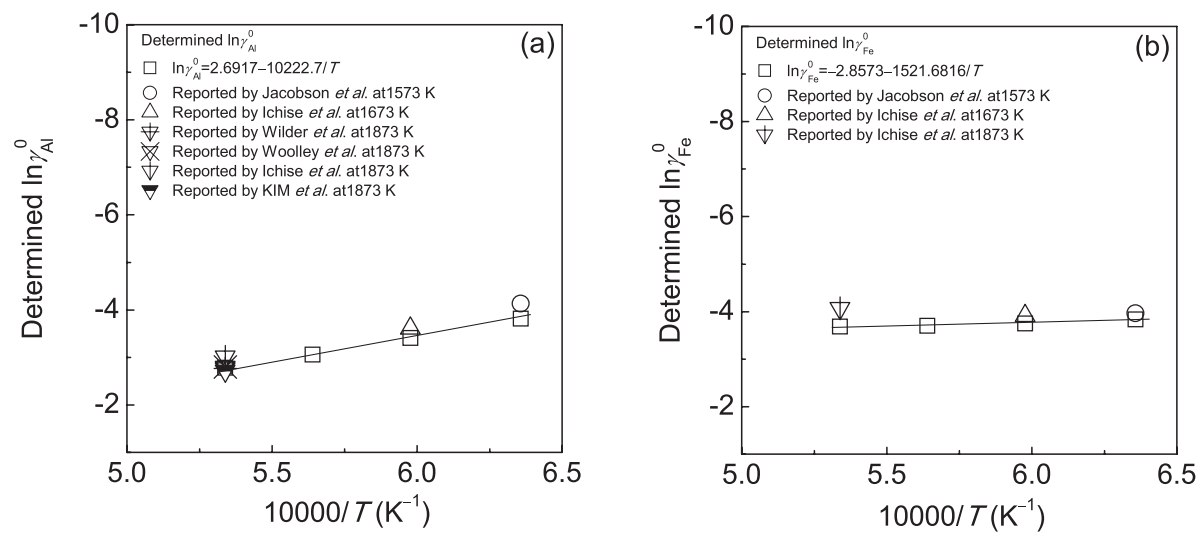

Fig. 3. Relationship between reciprocal of temperature $1 / T$ and calculated Raoultian activity coefficient of $\mathrm{Al}$ in logarithmic form $\ln \gamma_{\mathrm{Al}}^{0}(a)$, and relationship between reciprocal of temperature $1 / T$ and calculated Raoultian activity coefficient of $\mathrm{Fe}$ in logarithmic form $\ln \gamma_{\mathrm{Fe}}^{0}(b)$ in the infinitely dilute $\mathrm{Fe}-\mathrm{Al}$ binary melts in a temperature range from $1573 \mathrm{~K}$ to $1873 \mathrm{~K}$.

illustrated in Fig. 3 and can be regressed as

$$
\begin{aligned}
& \ln \gamma_{\mathrm{Al}}^{0}=2.6917-10222.7 / T \\
& 1573 \mathrm{~K} \leq T \leq 1873 \mathrm{~K}(-)
\end{aligned}
$$

Similarly, the Raoultian activity coefficient $\gamma_{\mathrm{Fe}}^{0}$ of $\mathrm{Fe}$ in $\mathrm{Fe}-\mathrm{Al}$ binary melts related with activity $a_{\mathrm{R}, \mathrm{Fe}}$ of $\mathrm{Fe}$ can be defined as the value of $\gamma_{\mathrm{Fe}, x_{\mathrm{Fe}} \rightarrow 0.0}$. Therefore, the intercepts of the linear functions in Eq. (11) and in Fig. 2(b) can be considered as the values of the Raoultian activity coefficient $\ln \gamma_{\mathrm{Fe}}^{0}$ of $\mathrm{Fe}$ in $\mathrm{Fe}-\mathrm{Al}$ binary melts at the above-mentioned four temperatures. The effect of temperature from $1573 \mathrm{~K}$ to $1873 \mathrm{~K}$ on the determined Raoultian activity coefficient in natural logarithmic form $\ln \gamma_{\mathrm{Fe}}^{0}$ of $\mathrm{Fe}$ in $\mathrm{Fe}-\mathrm{Al}$ binary melts was illustrated in Fig. 3(b) and can be regressed as 
Table 4. Comparison of reported activity coefficient $\gamma_{\mathrm{Al}}^{0}$ and $\gamma_{\mathrm{Fe}}^{0}$ in $\mathrm{Fe}-\mathrm{Al}$ binary melts from different researchers.

\begin{tabular}{|c|c|c|c|c|c|c|}
\hline No. & Investigator & $\mathrm{T}(\mathrm{K})$ & $\gamma_{\mathrm{Al}}^{0}(-)$ & $\gamma_{\mathrm{Fe}}^{0}(-)$ & Method & Ref \\
\hline 1 & Jacobson & 1573 & 0.016 & 0.019 & Ion-current-ratio technique & 8) \\
\hline 2 & Ichise & 1673 & 0.027 & 0.02 & $\begin{array}{l}\text { Knudsen Cell Mass } \\
\text { Spectrometry }\end{array}$ & 7) \\
\hline 4 & Wilder & 1873 & 0.063 & - & $\begin{array}{c}\mathrm{Fe}-\mathrm{Al} / \mathrm{Ag}-\mathrm{Al}(\text { estimated from } \\
\text { Chipman's data) }\end{array}$ & 3) \\
\hline 5 & Woolley & 1873 & 0.061 & - & Heats of solution in $\mathrm{Fe}-\mathrm{Al}$ & 4) \\
\hline 7 & Ichise & 1873 & 0.049 & 0.017 & $\begin{array}{c}\text { Knudsen Cell Mass } \\
\text { Spectrometry }\end{array}$ & 7) \\
\hline 8 & KIM & 1873 & 0.066 & - & Meta-gas equilibration & 9) \\
\hline 9 & Present study & 1573 & 0.022 & 0.021 & AMCT $-N_{i}$ model & - \\
\hline 10 & Present study & 1673 & 0.033 & 0.023 & AMCT $-N_{i}$ model & - \\
\hline 11 & Present study & 1773 & 0.047 & 0.0247 & AMCT $-N_{i}$ model & - \\
\hline 12 & Present study & 1873 & 0.062 & 0.025 & AMCT $-N_{i}$ model & - \\
\hline
\end{tabular}$$
\ln \gamma_{\mathrm{Fe}}^{0}=-2.8573-1521.6816 / T
$$

To evaluate the reliability of Eqs. (12) and (13) in this study, several reported Raoultian activity coefficient $\ln \gamma_{\mathrm{Al}}^{0}$ of $\mathrm{Al}$ and $\ln \gamma_{\mathrm{Fe}}^{0}$ of $\mathrm{Fe}$ by previous researchers ${ }^{3,4,7-9)}$ were summarized in Table 4 and displayed in Fig. 3 for comparison. Obviously, the reported $\ln \gamma_{\mathrm{Al}}^{0}$ of Al by previous researchers have good agreement with the determined Raoultian activity coefficient $\ln \gamma_{\mathrm{Al}}^{0}$ of $\mathrm{Al}$ in the infinitely dilute $\mathrm{Fe}-\mathrm{Al}$ binary melts. This suggests that the determined Raoultian activity coefficient $\ln \gamma_{\mathrm{Al}}^{0}$ of $\mathrm{Al}$ in the infinitely dilute $\mathrm{Fe}-\mathrm{Al}$ binary melts in a temperature range from 1573 $\mathrm{K}$ to $1873 \mathrm{~K}$ has an ideal accuracy. Meanwhile, the accuracy of the predicted Raoultian activity coefficient $\ln \gamma_{\mathrm{Fe}}^{0}$ of Fe in $\mathrm{Fe}-\mathrm{Al}$ binary melts in a temperature range from $1573 \mathrm{~K}$ to $1873 \mathrm{~K}$ can be verified from Fig. 3(b).

\subsection{Prediction of Mass Action Concentrations $N_{i}$ of Structural Units in Full Composition Range of Fe- Al Binary Melts}

As a representative, the relationship between mole fraction $x_{\mathrm{Al}}$ of $\mathrm{Al}$ and the calculated mass action concentrations $N_{i}$ of seven structural units as $\mathrm{Fe}, \mathrm{Al}, \mathrm{Fe}_{3} \mathrm{Al}, \mathrm{FeAl}, \mathrm{FeAl}_{2}$, $\mathrm{Fe}_{2} \mathrm{Al}_{5}$ and $\mathrm{FeAl}_{6}$ in the full composition range of $\mathrm{Fe}-\mathrm{Al}$ binary melts at $1873 \mathrm{~K}$ was illustrated in Fig. 4. The effect of changing temperature from $1573 \mathrm{~K}$ to $1873 \mathrm{~K}$ on the relationship of the calculated mass action concentrations $N_{i}$ of seven structural units as $\mathrm{Fe}, \mathrm{Al}, \mathrm{Fe}_{3} \mathrm{Al}, \mathrm{FeAl}, \mathrm{FeAl}_{2}$, $\mathrm{Fe}_{2} \mathrm{Al}_{5}$ and $\mathrm{FeAl}_{6}$ against mole fraction $x_{\mathrm{Al}}$ of $\mathrm{Al}$ in the full composition range of $\mathrm{Fe}-\mathrm{Al}$ binary melts was shown in Fig. 5 , respectively.

It can be observed from Figs. 4 and 5(a) that the calculated mass action concentration $N_{\mathrm{Al}}$ of $\mathrm{Al}$ shows a slow increase tendency with an increase of mole fraction $x_{\mathrm{Al}}$ of $\mathrm{Al}$ from 0 to 0.40 , and then displays a sharp increase trend with an increase of mole fraction $x_{\mathrm{Al}}$ of $\mathrm{Al}$ from 0.40 to 1.0 at the above-mentioned four temperatures. Meanwhile, an opposite variation trend of the calculated mass action concentration $N_{\mathrm{Fe}}$ of Fe against mole fraction $x_{\mathrm{Fe}}$ of Fe can be found at the above-mentioned four temperatures. Changing

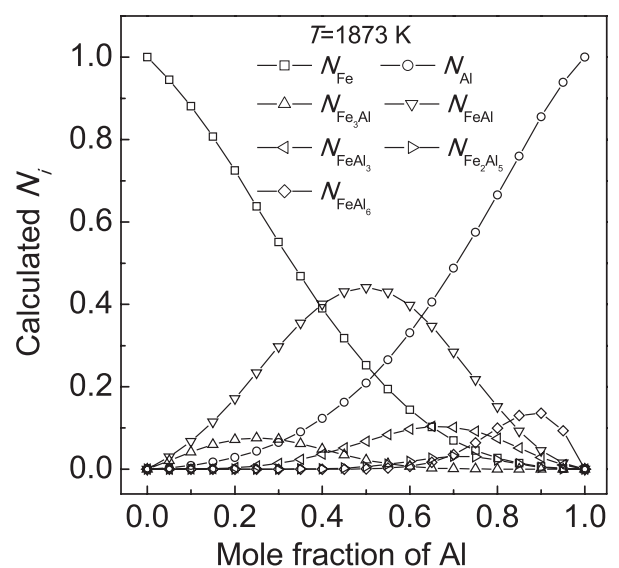

Fig. 4. Relationship between mole fraction $x_{\mathrm{Al}}$ of $\mathrm{Al}$ and calculated mass action concentration $N_{i}$ of seven structural units as Fe, $\mathrm{Al}, \mathrm{Fe}_{3} \mathrm{Al}, \mathrm{FeAl}, \mathrm{FeAl}_{2}, \mathrm{Fe}_{2} \mathrm{Al}_{5}$ and $\mathrm{FeAl}_{6}$ in the full composition range of $\mathrm{Fe}-\mathrm{Al}$ binary melts at an interval of mole fraction $x_{\mathrm{A} 1}$ of $\mathrm{Al}$ as 0.05 , respectively.

temperature from $1573 \mathrm{~K}$ to $1873 \mathrm{~K}$ cannot cause an obvious variation on the calculated mass action concentration $N_{\mathrm{Al}}$ of $\mathrm{Al}$ as well as $N_{\mathrm{Fe}}$ of $\mathrm{Fe}$ as shown in Figs. 4 and 5(a), respectively.

The reverse V-type relationship between mole fraction $x_{\mathrm{Al}}$ of $\mathrm{Al}$ and the calculated mass action concentration $\mathrm{Fe}_{3} \mathrm{Al}, \mathrm{FeAl}, \mathrm{FeAl}_{2}, \mathrm{Fe}_{2} \mathrm{Al}_{5}$ and $\mathrm{FeAl}_{6}$ in the full composition range of $\mathrm{Fe}-\mathrm{Al}$ binary melts at temperatures of $1573 \mathrm{~K}$, $1673 \mathrm{~K}, 1773 \mathrm{~K}$, and $1873 \mathrm{~K}$ can be found in Figs. 5(b)5(f). As shown in Figs. 5(c) and 5(f), changing temperature from $1573 \mathrm{~K}$ to $1873 \mathrm{~K}$ cannot cause an obvious variation on the calculated mass action concentration $N_{\mathrm{FeAl}}$ of FeAl or $N_{\mathrm{FeAl}_{6}}$ of $\mathrm{FeAl}_{6}$ in $\mathrm{Fe}-\mathrm{Al}$ binary melts. The greatest value of the calculated mass action concentration $N_{\mathrm{FeAl}}$ of $\mathrm{FeAl}$ is 0.75 corresponds to mole fraction $x_{\mathrm{Al}}$ of $\mathrm{Al}$ as 0.5 ; the largest value of the calculated mass action concentration $N_{\mathrm{FeAl}_{6}}$ of $\mathrm{FeAl}_{6}$ is 0.064 corresponds to mole fraction $x_{\mathrm{Al}}$ of $\mathrm{Al}$ as 0.9 . This implies that the magnitude of the calculated mass action concentration $N_{\mathrm{c} i}$ of molecule $\mathrm{c} i$ as $\mathrm{Fe}_{x} \mathrm{Al}_{y}$ has a close relationship with the ratio of atom $\mathrm{Fe}$ to atom $\mathrm{Al}$.

As shown in Fig. 5(b), the maximum value of the calculated mass action concentration $N_{\mathrm{Fe}_{3} \mathrm{Al}}$ of $\mathrm{Fe}_{3} \mathrm{Al}$ is 0.152 corresponds to mole fraction $x_{\mathrm{Al}}$ of $\mathrm{Al}$ as 0.2 at $1573 \mathrm{~K}$; the greatest value of the calculated mass action concentration $N_{\mathrm{Fe}_{3} \mathrm{Al}}$ of $\mathrm{Fe}_{3} \mathrm{Al}$ as 0.08 meets mole fraction $x_{\mathrm{Al}}$ of $\mathrm{Al}$ as 0.3 at $1873 \mathrm{~K}$. Increasing temperature from $1573 \mathrm{~K}$ to $1873 \mathrm{~K}$ can lead to a decrease of the maximum value of the calculated mass action concentration $N_{\mathrm{Fe}_{3} \mathrm{Al}}$ of $\mathrm{Fe}_{3} \mathrm{Al}$ from 0.152 to 0.08 . As illustrated in Fig. 5(d), the largest value of the calculated mass action concentration $N_{\mathrm{FeAl}_{2}}$ of $\mathrm{FeAl}_{2}$ is 0.102 corresponds to mole fraction $x_{\mathrm{Al}}$ of $\mathrm{Al}$ as 0.6 at 1873 $\mathrm{K}$; the greatest value of the calculated mass action concentration $N_{\mathrm{FeAl}_{2}}$ of $\mathrm{FeAl}_{2}$ is 0.0136 corresponds to mole fraction $x_{\mathrm{Al}}$ of $\mathrm{Al}$ as 0.6 at $1573 \mathrm{~K}$. Increasing temperature from $1573 \mathrm{~K}$ to $1873 \mathrm{~K}$ can cause an increase of the largest value of the calculated mass action concentration $N_{\mathrm{FeAl}_{2}}$ of $\mathrm{FeAl}_{2}$ from 0.102 to 0.0136 . As described in Fig. 5(e), the largest value of the calculated mass action concentration $N_{\mathrm{Fe}_{2} \mathrm{Al}_{5}}$ of $\mathrm{Fe}_{2} \mathrm{Al}_{5}$ as 0.1 corresponds to mole fraction $x_{\mathrm{Al}}$ of $\mathrm{Al}$ as 0.7 at $1573 \mathrm{~K}$; the greatest value of the calculated mass action concentration $N_{\mathrm{Fe}_{2} \mathrm{Al}_{5}}$ of $\mathrm{Fe}_{2} \mathrm{Al}_{5}$ is 0.0312 corresponds to 

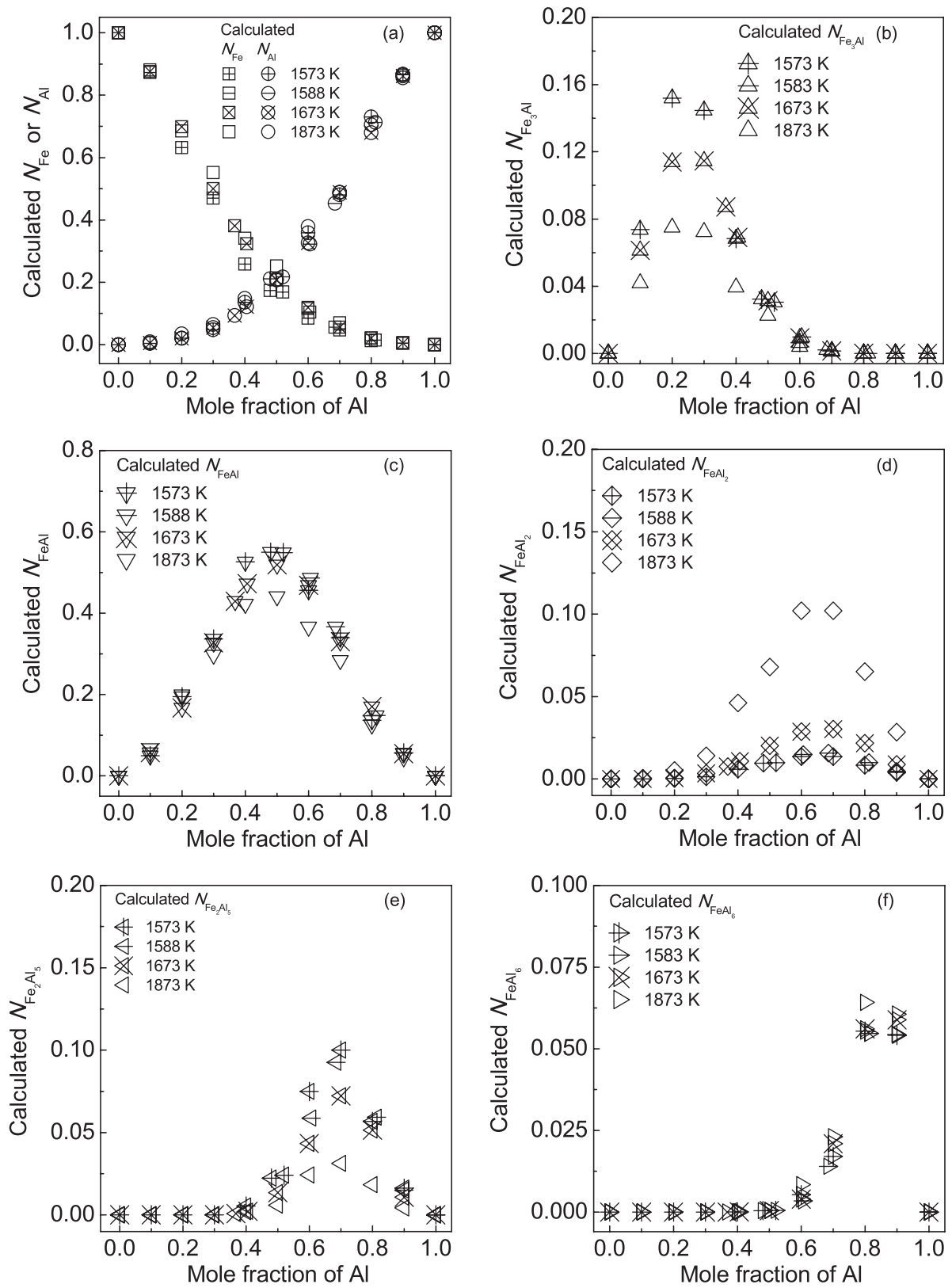

Fig. 5. Relationship between mole fraction $x_{\mathrm{Al}}$ of $\mathrm{Al}$ and calculated mass action concentration $N_{i}$ of seven structural units as $\mathrm{Fe}, \mathrm{Al}, \mathrm{Fe}_{3} \mathrm{Al}, \mathrm{FeAl}, \mathrm{FeAl}_{2}, \mathrm{Fe}_{2} \mathrm{Al}_{5}$ and $\mathrm{FeAl}_{6}$ in the full composition range of $\mathrm{Fe}-\mathrm{Al}$ binary melts at temperatures of $1573 \mathrm{~K}, 1588 \mathrm{~K}, 1673 \mathrm{~K}$, and $1873 \mathrm{~K}$, respectively.

mole fraction $x_{\mathrm{Al}}$ of $\mathrm{Al}$ as 0.037 at $1873 \mathrm{~K}$. Increasing temperature from $1573 \mathrm{~K}$ to $1873 \mathrm{~K}$ can cause a decrease of the largest value of the calculated mass action concentration $N_{\mathrm{Fe}_{2} \mathrm{Al}_{5}}$ of $\mathrm{Fe}_{2} \mathrm{Al}_{5}$ from 0.1 to 0.0312 .

It should be specially emphasized that the sum of the calculated mass action concentrations $N_{i}$ of seven structural units as $\mathrm{Fe}, \mathrm{Al}, \mathrm{Fe}_{3} \mathrm{Al}, \mathrm{FeAl}, \mathrm{FeAl}_{2}, \mathrm{Fe}_{2} \mathrm{Al}_{5}$ and $\mathrm{FeAl}_{6}$ in $\mathrm{Fe}-$ Al binary melts should be unity as 1 as expressed in Eq. (4) in Section 2.1. Therefore, the calculated mass action concentration $N_{i}$ of seven structural units in $\mathrm{Fe}-\mathrm{Al}$ binary melts should be competitive or coupled each other. The competitive or coupled effect of the calculated mass action concentrations $N_{i}$ of seven structural units in $\mathrm{Fe}-\mathrm{Al}$ binary melts is also valid in the cases changing temperature from $1573 \mathrm{~K}$ to $1873 \mathrm{~K}$.

\subsection{Relationship between Calculated Equilibrium Mole Number $n_{i}$ and Mole Fraction of $x_{i}$ of Struc- tural Units in Fe-Al Binary Melts}

It has been described in Section 2.2 that the calculated equilibrium mole numbers $n_{i}$ is an important parameter to represent mass content of structural units in $\mathrm{Fe}-\mathrm{Al}$ binary melts under equilibrium, like mole fraction $x_{\mathrm{Al}}$ of $\mathrm{Al}$ or mole fraction $x_{\mathrm{Fe}}$ of $\mathrm{Fe}$, according the $\mathrm{AMCT}^{11,18-20)}$ or the IMCT. $^{22,23)}$

The relationship of the calculated equilibrium mole number $n_{i}$ of each structural unit against mole fraction $x_{\mathrm{Al}}$ of Al shown in Fig. 6 is similar with that of the calculated mass action concentration $N_{i}$ of each structural unit against mole fraction $x_{\mathrm{Al}}$ of $\mathrm{Al}$ in $\mathrm{Fe}-\mathrm{Al}$ binary melts at the abovementioned four temperatures as shown in Fig. 5. Changing temperature from $1573 \mathrm{~K}$ to $1873 \mathrm{~K}$ cannot bring an obvious variation on the calculated equilibrium mole number $n_{\mathrm{Fe}}$ 

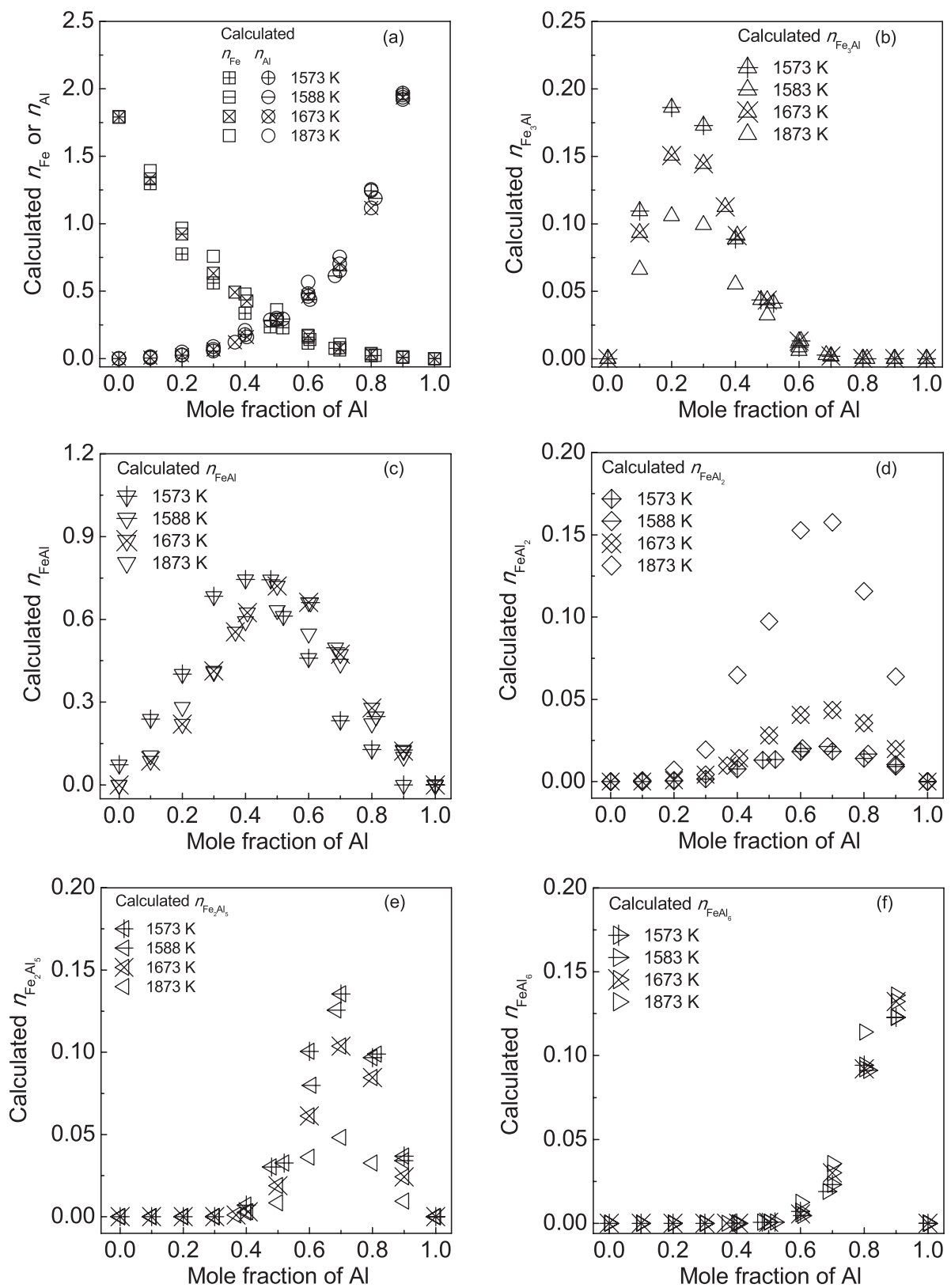

Fig. 6. Relationship between mole fraction $x_{\mathrm{Al}}$ of $\mathrm{Al}$ and calculated equilibrium mole numbers $n_{i}$ of seven structural units as $\mathrm{Fe}, \mathrm{Al}, \mathrm{Fe}_{3} \mathrm{Al}, \mathrm{FeAl}, \mathrm{FeAl}_{2}, \mathrm{Fe}_{2} \mathrm{Al}_{5}$ and $\mathrm{FeAl}_{6}$ in the full composition range of $\mathrm{Fe}-\mathrm{Al}$ binary melts at temperatures of $1573 \mathrm{~K}, 1588 \mathrm{~K}, 1673 \mathrm{~K}$, and $1873 \mathrm{~K}$, respectively.

of Fe as well as $n_{\mathrm{Al}}$ of $\mathrm{Al}$, respectively. It can be observed from Fig. 6(a) that the calculated equilibrium mole number $n_{\mathrm{Al}}$ of $\mathrm{Al}$ shows a slow increase tendency with an increase of mole fraction $x_{\mathrm{Al}}$ of $\mathrm{Al}$ from 0.0 to 0.4 , and then displays a sharp increase trend with an increase of mole fraction $x_{\mathrm{Al}}$ of $\mathrm{Al}$ from 0.4 to 1.0. An opposite variation trend of the calculated equilibrium mole number $n_{\mathrm{Fe}}$ of $\mathrm{Fe}$ against mole fraction $x_{\mathrm{Al}}$ of $\mathrm{Al}$ can also be found from Fig. 6(a).

As shown in Figs. 6(c) and 6(f), changing temperature from $1573 \mathrm{~K}$ to $1873 \mathrm{~K}$ cannot cause an obvious variation of the calculated equilibrium mole number $n_{\mathrm{FeAl}}$ of $\mathrm{FeAl}$ and $n_{\mathrm{FeAl}_{6}}$ of $\mathrm{FeAl}_{6}$ in $\mathrm{Fe}-\mathrm{Al}$ binary melts. The greatest value of the calculated equilibrium mole number $n_{\mathrm{FeAl}}$ is 0.75 corresponds to mole fraction $x_{\mathrm{Al}}$ of $\mathrm{Al}$ as 0.5 ; the largest value of the calculated equilibrium mole number $n_{\mathrm{FeAl}_{6}}$ of $\mathrm{FeAl}_{6}$ is 0.136 corresponds to mole fraction $x_{\mathrm{Al}}$ of $\mathrm{Al}$ as 0.9 .

As described in Fig. 6(b), increasing temperature from
$1573 \mathrm{~K}$ to $1873 \mathrm{~K}$ can lead to a decrease tendency of the maximum value of the calculated equilibrium mole number $n_{\mathrm{Fe}_{3} \mathrm{Al}}$ of $\mathrm{Fe}_{3} \mathrm{Al}$ from 0.186 to 0.106 . The maximum value of the calculated equilibrium mole number $n_{\mathrm{Fe}_{3} \mathrm{Al}}$ of $\mathrm{Fe}_{3} \mathrm{Al}$ is 0.186 corresponds to mole fraction $x_{\mathrm{Al}}$ of $\mathrm{Al}$ as 0.2 at 1573 $\mathrm{K}$; the greatest value of the calculated equilibrium mole number $n_{\mathrm{Fe}_{3} \mathrm{Al}}$ of $\mathrm{Fe}_{3} \mathrm{Al}$ as 0.106 meets mole fraction $x_{\mathrm{Al}}$ of $\mathrm{Al}$ as 0.2 at $1873 \mathrm{~K}$. As illustrated in Fig. 6(d), increasing temperature from $1573 \mathrm{~K}$ to $1873 \mathrm{~K}$ can lead to an increase tendency of the maximum value of the calculated equilibrium mole number $n_{\mathrm{FeAl}_{2}}$ of $\mathrm{FeAl}_{2}$ from 0.0184 to 0.158 corresponds to mole fraction $x_{\mathrm{Al}}$ of $\mathrm{Al}$ as 0.7 . As shown in Fig. $6(\mathrm{e})$, increasing temperature from $1573 \mathrm{~K}$ to $1873 \mathrm{~K}$ can cause a decrease tendency of the maximum value of the calculated equilibrium mole number $n_{\mathrm{Fe}_{2} \mathrm{Al}_{5}}$ of $\mathrm{Fe}_{2} \mathrm{Al}_{5}$ from 0.135 to 0.482 meets mole fraction $x_{\mathrm{Al}}$ of $\mathrm{Al}$ as 0.7 . 


\section{Conclusions}

A thermodynamic model for calculating the mass action concentrations of structural units in $\mathrm{Fe}-\mathrm{Al}$ binary melts based on the atom-molecule coexistence theory, i.e., AMCT $-N_{i}$ model, has been developed and verified through comparing with the reported activities of both $\mathrm{Al}$ and $\mathrm{Fe}$ in $\mathrm{Fe}-\mathrm{Al}$ binary melts in a temperature from $1573 \mathrm{~K}$ to 1873 $\mathrm{K}$ from the literature. The main summary remarks can be obtained as follows.

(1) The calculated mass action concentration $N_{\mathrm{Al}}$ of $\mathrm{Al}$ or $N_{\mathrm{Fe}}$ of $\mathrm{Fe}$ in $\mathrm{Fe}-\mathrm{Al}$ binary melts has a good 1:1 corresponding relationship with the reported activity $a_{\mathrm{R}, \mathrm{Al}}$ of $\mathrm{Al}$ or $a_{\mathrm{R}, \mathrm{Fe}}$ of $\mathrm{Fe}$ relative to pure liquid $\mathrm{Al}(\mathrm{l})$ or $\mathrm{Fe}(\mathrm{l})$ as standard state in a temperature range from $1573 \mathrm{~K}$ to $1873 \mathrm{~K}$ from different researchers. The calculated mass action concentration $N_{\mathrm{Al}}$ of $\mathrm{Al}$ or $N_{\mathrm{Fe}}$ of Fe can be applied to ideally substitute the measured activity $a_{\mathrm{R}, \mathrm{Al}}$ of $\mathrm{Al}$ or $a_{\mathrm{R}, \mathrm{Fe}}$ of Fe relative to pure liquid $\mathrm{Al}(\mathrm{l})$ or $\mathrm{Fe}(\mathrm{l})$ as standard state in $\mathrm{Fe}-\mathrm{Al}$ binary melts. Therefore, the developed AMCT $-N_{i}$ model for $\mathrm{Fe}-\mathrm{Al}$ binary melts can be successfully applied to represent the reaction ability of structural units in $\mathrm{Fe}-\mathrm{Al}$ binary melts in a temperature from $1573 \mathrm{~K}$ to $1873 \mathrm{~K}$.

(2) The values of the Raoultian activity coefficient $\gamma_{\mathrm{Al}}^{0}$ of $\mathrm{Al}$ and $\gamma_{\mathrm{Fe}}^{0}$ of $\mathrm{Fe}$ in the infinitely dilute solution of $\mathrm{Fe}-$ Al binary melts in a temperature range from $1573 \mathrm{~K}$ to $1873 \mathrm{~K}$ can be expressed as $\ln \gamma_{\mathrm{Al}}^{0}=2.6917-10222.7 / T$ and $\ln \gamma_{\mathrm{Fe}}^{0}=-2.8573-1521.6816 / T$, respectively. The calculated values of the Raoultian activity coefficient $\gamma_{\mathrm{Al}}^{0}$ of $\mathrm{Al}$ or $\gamma_{\mathrm{Fe}}^{0}$ of Fe has good agreement with the reported $\gamma_{\mathrm{Al}}^{0}$ of $\mathrm{Al}$ or $\gamma_{\mathrm{Fe}}^{0}$ of Fe by previous researchers.

(3) The reaction abilities of structure units $\mathrm{Fe}, \mathrm{Al}$, $\mathrm{Fe}_{3} \mathrm{Al}, \mathrm{FeAl}, \mathrm{FeAl}_{2}, \mathrm{Fe}_{2} \mathrm{Al}_{5}$ and $\mathrm{FeAl}_{6}$ show a competitive or coupling relationship in the investigated temperature range.

\section{REFERENCES}

1) A. K. Misra: Metall. Mater. Trans. A, 21A (1990), 441.

2) J. Chipman and T. P. Floridis: Acta Metall., 3 (1955), 456.

3) T. C. Wilder and J. F. Elliott: J. Electro. Chem. Soc., 107 (1960), 628.

4) F. Wooley and J. F. Elliott: Trans. Met. Soc. AIME, 239 (1967), 1872.

5) A. Coskun and J. F. Elliott: Trans. Met. Soc. AIME, 242 (1968), 253.

6) G. R. Belton and R. J. R. Fruehan: Trans. Met. Soc. AIME, 245 (1969), 113.

7) E. Ichise, T. Yamauchi and T. Mori: Tetsu-to-Hagané, 63 (1977), 417.

8) N. S. Jacobson and G. M. Mehrotra: Metall. Mater. Trans. B, 24B (1993), 481.

9) W. Y. Kim, J. G. Kang, C. H. Park, J. B. Lee and J. J. Pak: ISIJ Int., 47 (2007), 945.

10) A. I. Zaitsev, N. E. Zaitseva, R. Y. Shimko, N. A. Arutyunyan, S. F. Dunaev, V. S. Kraposhin and H. T. Lam: J. Phys.: Condens. Matter., 20 (2008), 114121.

11) J. Zhang: J. Iron Steel Res., Int., 12 (2005), 11.

12) A. D. Pelton, S. A. Degterov, G. Eriksson, C. Robelin and Y. Dessureault: Metall. Mater. Trans. B, 31B (2000), 651

13) D. W. Hoffman: Metall. Trans., 3 (1972), 3231.

14) Y. E. Lee: Metall. Mater. Trans. B, 29B (1998), 397.

15) M. Le Bouteiller, A. M. Martre, R. Farhi and C. Petot: Metall. Mater. Trans. B, 1B (1977), 339.

16) P. Chartrand and A. D. Pelton: Metall. Mater. Trans. A, 32A (2001), 1397.

17) F. Sommer: Z. Metallkd., 73 (1982), 72

18) J. Zhang: Computational Thermodynamics of Metallurgical Melts and Solutions, Metallurgical Industry Press, Beijing, China, (2007), 40 .

19) X. M. Yang, M. Zhang, P. C. Li, J. Y. Li, J. L. Zhang and J. Zhang: Metall. Mater. Trans. B, 43B (2012), 1358.

20) X. M. Yang, M. Zhang, P. C. Li, J. Y. Li, J. L. Zhang and J. Zhang: Steel Res. Int., 84 (2013), 784.

21) P. D. Desai: J. Phys. Chem. Ref. Data, 16 (1987), 109.

22) X. M. Yang, J. S. Jiao, R. C. Ding, C. B. Shi and H. J. Guo: ISIJ Int., 49 (2009) 1828.

$23)$ C. B. Shi, X. M. Yang, J. S. Jiao, C. Li and H. J. Guo: ISIJ Int., 50 (2010), 1362.

24) J. H. Hildebrand and E. D. Eastman: J. Am. Chem. Soc., 37 (1915), 2452.

25) R. C. Sharma and Y. A. Chang: Metall. Mater. Trans. B, 10B (1979), 103.

26) Y. Y Chuang, K. C. Hsieh and Y. A. Chang: Metall. Mater. Trans. $B, 16 B$ (1985), 277. 